\title{
INSTITUTE OF GEOLOGICAL SCIENCES RADIOCARBON DATES II
}

\author{
E. WELIN, L. ENGSTRAND, and S. VACZY
}

Radioactive Dating Laboratory, S-10405, Stockholm 50, Sweden*

This date list was compiled by the Institute of Geological Sciences (U.K.) incorporating data supplied under contract by E. Welin, Radioactive Dating Laboratory, Stockholm. Unless otherwise stated, age figures are in $\mathrm{C}^{14}$ years before A.D. 1950. The half-life of $\mathrm{C}^{14}$ is taken as 5568 and the standard error is given as a standard deviation of $1 \sigma$. Correction for $\mathrm{C}^{13} / \mathrm{C}^{12}$ has not been made.

\section{South Shian series}

Shells from glacially disturbed marine clay in low cliff at S Shian, Argyllshire (56 $32^{\prime} \mathrm{N}$ Lat, $5^{\circ} 24^{\prime} \mathrm{W}$ Long, Grid Ref. NM 909 422), exposed about high-tide level beneath glacial sand. Coll. 1969 by J. D. Peacock, D. Mottershead, and J. C. C. Romans; subm. by J. D. Peacock, Inst. of Geol. Sci.

\section{IGS-C14/16. (St 3262/3332)}

a) Valves of pelecypod Chlamys islandica.

\section{IGS-C14/17. (St 3263)}

b) Valves of pelecypod Astarte elliptica.

IGS-C14/18. (St 3266/3306)

c) Mixed shell debris.

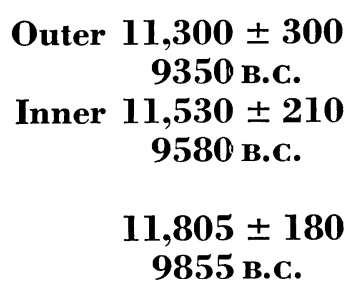

Outer $11,300 \pm 300$ 9350 B.C.

Inner $11,530 \pm 210$ 9580 B.c.

$$
11,805 \pm 180
$$$$
9855 \text { B.C. }
$$

$$
\begin{gathered}
\text { Outer } 6705 \pm 130 \\
4755 \text { B.c. } \\
\text { Inner } 11,430 \pm 220 \\
9480 \text { B.c. }
\end{gathered}
$$

General Comment (J.D.P.): results confirm that marine clay is of Aller $\phi \mathrm{d}$ age and that overlying glacial deposit was laid down during the Loch Lomond Readvance. Difference of dates on the 2 mollusk species is only slightly greater than statistical error, and is probably not significant. Poor results of determinations on mixed shell debris underlines value of unbroken shell valves for radiocarbon dating.

\section{IGS-C14/19. (St 3267) Dumbarton Distillery Borehole \\ $11,805 \pm 205$ 9855 B.C.}

Valves of pelecypod Chlamys islandica from marine horizon between alt -24.7 and $-41.8 \mathrm{~m}$ in borehole at Dumbarton $\left(55^{\circ} 57^{\prime} \mathrm{N}\right.$ Lat, 4 $34^{\prime}$ W Long, Grid Ref. NS 396 752). Coll. 1938. Subm. by J. D.

* Published by permission of the Director, Institute of Geological Sciences, Exhibition Road, London, S.W.7. The Institute is a contracting agency, not a dating laboratory, yet IGS at London is the "author" when needed for interlaboratory communication. 
Peacock. Comment (J.D.P.): date shows that much of the deposit, which is in the buried channel of R. Leven, is of Aller $\phi \mathrm{d}$ and later age.

\section{IGS-C14/20. (St 3269/3333)} Gallowhill, Paisley
Outer 12,930 \pm 160 10,980 B.c.

Inner 15,625 \pm 240 13,675 B.c.

Valves of pelecypod Arctica islandica from marine clay exposed in temporary excavation, top of excavation $11 \mathrm{~m}$ O.D., at Gallowhill,

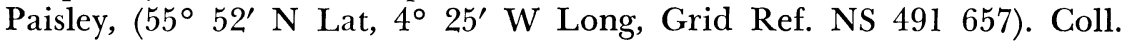
1938. Subm. by J. D. Peacock. Comment (J.D.P.): age greater than anticipated; additional specimen subm. for dating (see below).

IGS-C14/68. (St 3480/3481)

Gallowhill, Paisley

\section{Outer $12,125 \pm 210$ 10,175 в.c. \\ Inner 12,615 \pm 230 10,665 в.c.}

Comment (J.D.P.): revised dates agree with present knowledge of local geology.

$\begin{array}{ll}\text { IGS-C14/21. } & \text { (St 3270/3334) } \\ \text { Ralston, Paisley }\end{array}$

\section{Outer $12,890 \pm 360$ 10,940 B.c. \\ Inner $12,610 \pm 210$ 10,660 в.c.}

Valves of pelecypod Arctica islandica from marine clay exposed in temporary excavation, top of excavation ca. $16 \mathrm{~m}$ O.D., at Ralston, Paisley ( $55^{\circ} 51^{\prime} \mathrm{N}$ Lat, $4^{\circ} 23^{\prime} \mathrm{W}$ Long, Grid Ref. NS 510641 ). Coll. 1938. Subm. by J. D. Peacock. Comment (J.D.P.): date compares with that at Wester Fulwood (R., 1970, v. 12, p. 391) and indicates age of higher late-glacial marine sediments in Paisley area.

\section{IGS-C14/26. (St 3274) Bathampton, Somerset}

$8690 \pm 180$

Peat from Borehole 11 on line of proposed Batheaston By-Pass rd. $\left(51^{\circ} 24^{\prime} \mathrm{N}\right.$ Lat, $2^{\circ} 18^{\prime} \mathrm{W}$ Long, Grid Ref. ST 7850 6711) ca. $0.7 \mathrm{~m}$ above base of alluvium resting on Jurassic (Lower Lias) clay. Ground alt $20.25 \mathrm{~m}$. Borehole is on $\mathrm{S}$ margin of alluvial plain of $\mathrm{R}$. Avon above Bath. Presence of peat bed suggests valley floor was partly occupied by swamps and marshes at postglacial climatic optimum. Deposits overlying peat consist primarily of silty clay. Material presented by Le Grand Sutcliffe and Gell. Coll. 1965 and subm. by G. A. Kellaway, Inst. of Geol. Sci.

\section{Severnside series, Gloucestershire}

Peat and reworked organic silt from excavation for reservoir at Severnside, Avonmouth (51 $33^{\prime}$ N Lat, $2^{\circ} 39^{\prime}$ W Long, Grid Ref. ST 5461 8394). Coll. 1969 and subm. by A. B. Hawkins, Univ. of Bristol. 
IGS-C14/27. (St. 3257)

Peat layer at $+3.96 \mathrm{~m}$, between 2 estuarine clays.

IGS-C14/28. (St 3275)

Peat layer at $+3.35 \mathrm{~m}$, between 2 estuarine clays.

1955 B.c.

IGS-C14/25. (St 3273) Sandbach, Cheshire

$>40,000$

Wood from organic horizon brought up by suction-dredging from beneath Congleton Sand in Arclid Wood Quarry $\left(53^{\circ} 09^{\prime} \mathrm{N}\right.$ Lat, $2^{\circ}$ 20' W Long, Grid Ref. SJ 7767 6203). Coll. 1969 and subm. by W. B. Evans, Inst. of Geol. Sci. Nearby, boreholes show that horizon lies at ca. $48 \mathrm{~m}$ O.D., in white sands overlain in turn by Congleton Sand and late Devensian (Weichselian) till, and underlain by thin patches of sandy gravel and stony till. Comment: date consistent with suggestion (Evans et al., 1968, p. 213) that organic deposit is broadly comparable in age with that at Farm Wood Quarry, Chelford (R., 1970, v. 12, p. 385).

\section{IGS-C14/29. (St 3276)}

$5100 \pm 100$

Reworked organic silt at $1.73 \mathrm{~m}$ O.D.

General Comment (A.B.H.): forms part of Flandrian coastal sequence. There is no stratigraphic break above horizon of C14/27 as would be expected if area had been a land surface prior to inundation by the 'Romano British Transgression.' Upper $5 \mathrm{~m}$ of organic silt is bioturbated and contains Hydrobia sp.; bottom contact is irregular.

\section{Avonmouth Bridge series, Somerset}

Samples from bridge excavations.

\section{IGS-C14/30. (St 3277) Avonmouth Bridge 2355 B.c.}

Wood in peat band $0.56 \mathrm{~m}$ thick, at $3.45 \mathrm{~m}$ O.D., in excavation for pier $\left(51^{\circ} 30^{\prime} \mathrm{N}\right.$ Lat, $2^{\circ} 41^{\prime} \mathrm{W}$ Long, Grid Ref. ST 5234 7752). Peat rests on eroded surface of Keuper Marl and is overlain by Flandrian clay. Coll. 1969 and subm. by D. D. Gilbertson and A. B. Hawkins.

\section{IGS-C14/31. (St 3278) Avonmouth Bridge 2155 B.C.}

Roots in frost wedge within Keuper Marl, overlain by Flandrian clay, from excavation for pier, at $3.66 \mathrm{~m}$ O.D. $\left(51^{\circ} 30^{\prime} \mathrm{N}\right.$ Lat, $2^{\circ} 41^{\prime}$ W Long, Grid Ref. ST 5228 7738). Coll. 1969 and subm. by D. D. Gilbertson and A. B. Hawkins. Comment (A.B.H.): date indicates roots are contemporary with peat band (cf. IGS C14/30) and not with infilling of frost wedge. 


\section{IGS-C14/32. (St 3279) Undy Wharf, $3485 \pm 100$ Monmouthshire 1535 B.c.}

Wood in peat band, overlain by recent clay, exposed on foreshore $\left(51^{\circ} 34^{\prime} \mathrm{N}\right.$ Lat, $2^{\circ} 48^{\prime} \mathrm{W}$ Long, Grid Ref. ST 4441 8531). Part of submerged forest. Coll. 1969 and subm. by A. B. Hawkins.

Peat at $-7.77 \mathrm{~m}$ O.D. in borehole $\left(51^{\circ} 16^{\prime} \mathrm{N}\right.$ Lat, $2^{\circ} 55^{\prime} \mathrm{W}$ Long, Grid Ref. ST 3581 5283). Peat bed overlain by estuarine clay. Presented by Soil Mechanics Ltd. Coll. 1967 and subm. by A. B. Hawkins.

Peat at $-0.9 \mathrm{~m}$ O.D. in creek $\left(51^{\circ} 26^{\prime} \mathrm{N}\right.$ Lat, $2^{\circ} 53^{\prime} \mathrm{W}$ Long, Grid Ref. ST 3878 7039). Peat interbedded with estuarine clays. Coll. 1969 by D. D. Gilbertson. Subm. by A. B. Hawkins.

\section{IGS-C14/35. (St 3293) Clevedon, Somerset}

Peat at $0.23 \mathrm{~m}$ O.D. overlain by $6.1 \mathrm{~m}$ of estuarine clay in excavation for sewer trench $\left(51^{\circ} 26^{\prime} \mathrm{N}\right.$ Lat, $2^{\circ} 52^{\prime} \mathrm{W}$ Long, Grid Ref. ST 3957 7029). Coll. 1969 by D. D. Gilbertson. Subm. by A. B. Hawkins. Comment (A.B.H.): no indication of stratigraphic break above dated horizon.

\section{Kenn Pier series, Somerset}

Peat and wood in excavations for pumping sta. at Kenn Pier $\left(51^{\circ}\right.$ 25' N Lat, 2० 49' W Long, Grid Ref. ST 4335 6978). Coll. 1968 by D. D. Gilbertson. Subm. by A. B. Hawkins.

IGS-C14/36. (St 3294)

$3510 \pm 100$

Peat band $0.15 \mathrm{~m}$ thick, in estuarine clay, at $2.69 \mathrm{~m}$ O.D.

IGS-C14/37. (St 3295)

$\mathbf{3 4 1 0} \pm \mathbf{1 0 0}$

Peat band $0.1 \mathrm{~m}$ thick, in estuarine clay, at $2.24 \mathrm{~m}$ O.D.

IGS-C14/38. (St 3280)

$4145 \pm 100$

Wood from top of peat band, $1.09 \mathrm{~m}$ thick, at $-0.41 \mathrm{~m}$ O.D.

2195 B.c.

\section{IGS-C14/39. (St 3282)}

$6100 \pm 120$

Peat from bottom of same peat band is IGS C14/38 at $-1.50 \mathrm{~m}$ O.D. 
General Comment (A.B.H.): series of peat beds in Flandrian deposits of Kenn Moor. No stratigraphic break above horizon at Cl4/36.

\section{Weston-super-Mare series, Somerset}

Peat from Flandrian deposits from excavation for sewer trench at Weston-super-Mare $\left(51^{\circ} 21^{\prime} \mathrm{N}\right.$ Long, $2^{\circ} 57^{\prime} \mathrm{W}$ Long, Grid Ref. ST 3457 6194). Coll. 1969 by D. D. Gilbertson. Subm. by A. B. Hawkins.

\section{IGS-C14/40. (St 3296)}

$3675 \pm 100$ m O.D.

Peat from top of peat band, $1.22 \mathrm{~m}$ thick, in estuarine clay, at 1.60

\section{IGS-C14/41. (St. 3297)}

Peat from near base of same peat band at IGS C14/40, at 0.51 m O.D.

\section{REFERENCFS}

Evans, W. B., Wilson, A. A., Taylor, B. J., and Price, D., 1968, Geology of the country around Macclesfield, Congleton, Crewe and Middlewich: Geol. Survey of Great Britain Mem.

Shotton, F. W., Blundell, D. J., and Williams, R. E. G., 1970, Birmingham University radiocarbon dates IV: Radiocarbon, v. 12, p. 385-399. 